\title{
Making Up for a Loss: The Tragedy of Liang Shanbo and Zhu Yingtai in Modern Zaju
}

\author{
Wilt L. Idema
}

In 2008 Stephen Greenblatt, a well-known authority on Shakespeare, drew attention by publishing Cardenio, his own version of a lost play by Shakespeare. In an age when we study literature not in order to write it but to write about it, such an action may be more unusual than it was in earlier times when one studied literature in order to become an author oneself by imitation and emulation of the works of the masters. When literature became established as an academic discipline in China in the beginning of the twentieth century, the earliest generations of university teachers as well as college students as a rule still had been initiated to the study of literature in the traditional way: many of them were not only critics and historians of the genres they taught and read but also practitioners, showing their mastery of the subjects they taught by the works they produced on the side.

In the 1920 and 193 os this applied not only to essays, poems, and lyrics, but also in the field of traditional drama. ${ }^{1}$ If the pioneer scholar of drama history Wang Guowei 王國維 (1877-1927) never realized his ambition to write his own $z a j u$ 雜劇, other scholars did. In Nanjing the veteran playwright and drama scholar Wu Mei 吳梅 (1884-1939) stimulated his students such as Lu Qian 盧前 (1905-1951), Wang Jisi 王季思 (1906-1996), and Chang Renxia 常任俠 (19041996) to write their own sanqu 散曲 and zaju, ${ }^{2}$ but their works were eventually surpassed, both in quantity and quality, by the Beijing-based scholar Gu Sui 顧隨 (1897-1960). In the second part of the twentieth century the creative works of these scholars have been largely ignored, but in recent decades Zuo Pengjun 左鵬軍 in his many publications has not only provided a general

1 For a brief survey of the authors of zaju and chuanqi active in the period 1920-1949, see for instance Zuo Pengjun 左鵬軍, Jindai chuanqi zaju yanjiu 近代傳奇雜劇研究 (Guangzhou: Guangdong gaodeng jiaoyu chubanshe, 2001), 78-89. Yao Dahuai 姚大懷, “Minguo xuezhe zuojia de chunaqi zaju chuangzuo jiqi xiqushi yiyi” 民國學者作家的傳奇雜劇創作及其 戲曲史意義, Wenyi lilunyanjiu 2016.4: 142-51 highlights the growing prominence of academics among authors of zaju and chuanqi during the Republican era.

2 Zuo Pengjun, “Wu Mei dizi de chuanqi zaju ji qi xiqushi yiyi” 吴梅弟子的傳奇雜劇及其戲 曲史的意義, Xueshuyanjiu 2007.7: 137-42. 
picture, but also discussed the works of many individual authors. The works of Gu Sui had already earlier started to attract attention. ${ }^{3}$

In the wake of the Folklore Movement of the 1920 s many Chinese scholars had also developed an interest in the development and meaning of folktales. Following the example of Gu Jiegang's 顧頡剛 (1893-1980) studies on the tale of Meng Jiangnü 孟姜女, Qian Nanyang 錢南楊 (1899-1987) focused on the tale of Liang Shanbo 梁山伯 and Zhu Yingtai 祝英台, on which he first published in 1926. This tale of a girl who passes as a boy in order to pursue an advanced education away from home, and whose love for her roommate is thwarted when on her return home her parents marry her off to another young man, perfectly fitted the agenda of the May Fourth Movement with its emphasis on gender equality and free marriage choice. The tale was discussed more widely in a variety of media in the 1930s, following a triple special issue of the Canton-based periodical Minsu zhoukan 民俗周刊 in February 1930. ${ }^{4}$ One aspect of this "Liang-Zhu fever" of the 1930s that is hardly if ever discussed in surveys of early scholarship on the legend, is that the legend was twice adapted as a zaju to make up for the loss of the play on this topic by the famous Yuandynasty playwright $\mathrm{Bai} \mathrm{Pu}$ 白樸. This lost play was often mentioned by scholars on the legend to prove its early popularity on and off stage. ${ }^{5}$ The first modern zaju adaptation was authored in 1931 by Chang Renxia while he was still a student at the Central University in Nanjing; the second adaptation was written by Gu Sui in 1936, then teaching at Yanjing University. A comparison of these

3 Gu Sui and his works have been eagerly studied since the 199os. See Min Jun 閔軍, “Gu Sui yanjiu shuping” 顧随研究述評, Xuzhou shifan daxue xuebao 2006.3: 12-20; Zhao Lintao 趙林濤, “Guxue yanjiu fanchou” 顧學硏究范疇, Hebeixuekan 32.1 (2012): 90-93; Zhao Lintao and Gu Zhijing 顧之京, “Gu Sui xueshu nianbiao” 顧随學術年表, Hebei daxue xuebao 40.3 (2015): $3^{2-37}$.

4 Chang-tai Hung, Going to the People: Chinese Intellectuals and Folk Literature, 1918-1937 (Cambridge Mass.: Harvard Univ. Press, 1985) discusses the studies of these two folktales on pp. 93-103. For a more detailed analysis of Gu Jiegang's study and reinterpretation of the legend of MengJiangnü, see Haiyan Lee, "Tears That Crumbled the Great Wall:The Archaeology of Feeling in the May Fourth Folklore Movement," Journal of Asian Studies 64.1 (2005): $35^{-65}$.

5 Fu Xihua 傅惜華, Yuandai zaju quanmu 元代雜劇全目 (Beijing: Zuoja chubanshe, 1957), 7 . The full title of Bai's play is listed as Ma Hao'er buyu Lü Dongbin; Zhu Yingtai sihun Liang Shanbo 馬好兒不遇呂洞賓;祝英台死婚梁山伯 (Goodfellow Ma does not meet Lü Dongbin; Zhu Yingtai marries Liang Shanbo in death). The reference to Lü Dongbin in this title is puzzling. This immortal makes an appearance as a teacher of Liang Shanbo in some of the versions of the legend that include an account of the resurrection of the lovers and their further career, but his name is not found in any of the preserved early versions. Its occurrence here, however, might suggest that Bai Pu's adaptation already included the resurrection of the lovers alongside the death of Student Ma. The name of Student Ma is not mentioned in any of the earlier records of the legend. 
two plays may be helpful to bring out the characteristics of these two authors, and so perhaps be a small contribution to the study of modern zaju. A closer look at these two plays may also be of interest for the study of the legend of Liang Shanbo and Zhu Yingtai, because both authors did not base their adaptations on the best-known versions of the legend from the Jiangnan area, but on the local traditions of their hometowns in respectively northern Anhui and southern Hebei.

\section{Chang Renxia and His Zhu Liangyuan}

After 1949 Chang Renxia established himself as a major authority on ancient Chinese art. Students of early Chinese drama are of course acquainted with his monographs on ancient Chinese dance. But little in his early youth predicted such a scholarly career. Chang was born in a small village in Yingshang district in northern Anhui, north of the Huai River. Only at the age of ten sui did he start attending a traditional school (sishu 私塾). He was forced to leave his hometown in 1922 because of floods, but a generous gift from a brother-in-law allowed him to travel to Nanjing, where was admitted to the Special School for the Arts. Upon graduation from that school he was later admitted to the Central University, where he studied with $\mathrm{Wu}$ Mei. Upon graduation he was retained at his alma mater. The academic year $1935^{-} 36$ he spent in Japan, where he pursued an M.A. degree at Tokyo University.

Throughout the 1920s and early 1930s Chang Renxia was active in huaju 話劇 (modern spoken drama) activities in Nanjing as a critic, organizer, and actor. He played, for instance, a small part in Tian Han's 田漢 (1898-1968) Fuhuo 復活 (Resurrection; an adaptation of Tolstoy's novel Resurrection), when it was performed to great success in in Nanjing in the spring of 1936. Throughout the Anti-Japanese War (1937-45) Chang Renxia would continue to produce dramatic scripts. His first exposure to drama was, however, as a young boy to the various forms of local theater in his home village. Late in life he left a vivid description not only of his huaju activities but also of his childhood exposure to traditional theater:

As a child I grew up in Yingshang district in northern Anhui and I only went to school at ten. The dramatic arts that I encountered all were as local as local could be. Each year on the eighth day of the fourth month of the lunar calendar there would be a large local market fair where the farmers could buy and sell livestock and implements, and there you could find all kinds of locally-produced woodblock-printed small songbooks, 
some of which were local plays, and I collected not a few of them. At the time of the new year according to the lunar calendar people everywhere were selling woodblock-printed, brightly colored New Year prints, many of which showed dramatic scenes, and I also collected not a few of those. The local little plays you could see under normal circumstances were only the duangongxi 端宮戲 (danwuxi 擔巫戲) that were performed by only a handful of people: they would construct a coarse stage, high above the heads of the audience.... There they performed Mulian Saves His Mother, The Large Parting at the Inn, The Small Parting at the Inn, and Liang Shanbo and Zhu Yingtai. ${ }^{6}$

For more elaborate performances the young Chang Renxia had to wait for the annual festival in the district capital on the first of the tenth month. As a teenager he learned from a blind singer the tunes he performed, and he also learned to play the flute and the two-stringed fiddle. ${ }^{7}$

Despite Chang Renxia's active involvement in huaju activities in Nanjing, Wu Mei succeeded to also instill a passion for Yuan drama in his student:

In my studies at that time I emphasized China's classical literature. I was most interested in Yuan drama and the famous plays of Guan Hanqing 觀漢卿, Ma Zhiyuan 馬致遠, Zheng Guangzu 鄭光祖, and Bai Pu were always at my side. My teacher Wu Mei also provided me with additional instruction. At times he would in the classroom play the flute and correct the tune when lecturing on prosody. I have written a few short and long sanqu, and I also wrote the one-act plays Gupen'ge 鼓盆歌 (Singing while Drumming on a Pot) and Tian Heng dao 田橫島 (Tian Heng's Island), as well as the four-act script Zhu Liang yuan 祝梁怨 (Zhu Yingtai and Liang Shanbo's Grief). These were all published after they had been corrected by Wu Mei himself. 8

The text of Gupen'ge so far has not been recovered but must have been an adaptation of the well-known tale in which Zhuangzi's 莊子 friends upon the death of his wife find the philosopher drumming a pot and singing a song on ephemerality. Tian Heng dao was printed in the January 16, 1930 issue of the Guoli Zhongyang daxue banyuekan (Wenyizhuan hao) 國立中央大學牛月刊文

6 Chang Renxia, “Wo yu xiju yishu” 我與戲劇藝術, Xinwenxue shiliao 1993.2: 46. This article is also reprinted by Shen Ning 審寧 and Guo Shufen 郭淑芬 in Yaxiya zhi liming: Cheng Renxia xiju ji 亞細亞之黎明: 常任俠戲劇集 (Taipei: Xiuwei zixun keji, 2012), 5-11.

7 Ibid. 46.

8 Ibid., 48. 
藝專號. This little play is set in the present: on the occasion of a visit to the last hold-out of the ancient hero Tian Heng who chose suicide over defeat, the author's alter ego gives expression to his anti-Japanese patriotism. ${ }^{9}$ If the young author had voiced his noblest sentiments in these two little plays, he would appear to have written Zhu Liang yuan as a prank during a local flood in 1931, as we learn from the preface he wrote in December 1933:

When in earlier years I was a student at the Central University, I studied the methods of arranging suites and devising scenes with my teacher $\mathrm{Wu}$ Mei, and I also read northern plays with great joy, but even though I might understand their import in my heart I had not yet mastered their skill. As an experiment I wrote a few plays such as Gupen'ge, Tian Heng dao, and Jieyu hui 劫餘灰 (Ashes Remaining from a Kalpa) and the university had them printed, ${ }^{10}$ but I myself consider them failures and have now rejected them. In the summer of the year xinwei the capital (Nanjing) suffered from a great flood, and in the Chengxian 成賢 Dormitory where I was staying the water reached to one's knees in the first-floor rooms. I spent my days leaning on the window and watching the fishes, despondent because I could not go out. Thereupon I selected four stories, planning to compose four zaju to while away my time. In one or two days I had finished the first act. But when I had barely finished Zhu Liang yuan, I left for Lushan and I could not complete the project. During these last few years I have been quite busy and have not practiced this craft anymore. By chance rifling through my trunks, I found my old manuscript still there. When I promptly took it to my teacher, and after he had corrected it, I handed it to the printer. How could I dare call this a "publication"? It only serves as a memory. ${ }^{11}$

Despite these words of modesty, Chang Renxia must have thought quite highly of Zhu Liang yuan, as this preface was included when Chang had it printed in a limited edition of two hundred copies on the eve of his departure for Japan in $1935 .{ }^{12}$ He took these copies with him when he went to Tokyo, where he

9 For a discussion of this play, see Zuo Pengjun, Wan-Qing Minguo chuanqi zaju wenxian yu shishi yanjiu 晚清民國傳奇雜劇文獻與史實研究 (Beijing: Renmin wenxue chubanshe, 2011), 115-17.

10 Jieyuhui would appear to be lost.

11 Chang Renxia, Zhu Liang yuan zaju (Nanjing: 1935), 2a-b.

12 Wu Mei provided the title page calligraphy for this edition, which is now very hard to find in China. See Zuo Pengjun, Wan-Qing Minguo chuanqi zaju wenxian yu shishi yanjiu, 11719. I have consulted the online version of the copy kept in the Sōkōdō 雙紅堂 Collection 
presented his work to Japanese scholars of Chinese vernacular literature, who showed themselves duly impressed. Shionoya On 鹽谷溫 $(1878-1962)$ is said to have exclaimed that Chang's play merited comparison with the works of Guan Hanqing!

Chang's Zhu Liang yuan is a regular four-act zaju. In the first act Zhu Yingtai enters on stage in male attire. She relates that her parents, lacking a son, had raised her as a boy and told her, when she reached the age of sixteen, to accompany Liang Shanbo and study at an academy. In the three years at the academy he never has found out that she is a girl but happily shoulders tasks that are too heavy for her, such as hauling water. But now that the teacher's wife has discovered she is a girl, by plying her with alcohol and discovering her bound feet, she decides that Zhu Yingtai cannot stay any longer and will have to return home. Though Zhu Yingtai is very much in love with Liang Shanbo, she cannot but chide him for his foolishness, for instance in the following aria to the tune of Chenzui dong feng 沉醉東風

That silly student strictly abides by the rites and yielding,

So I on my part don't have to take any special precautions.

What a joke: you are so smart and intelligent but still such a muddled mess!

For several years we've shared one couch and one window,

But you only appreciated 'The Master said,' 'The Odes proclaim':

Yours may be called 'a mind free of evil' truly transcending all physical charms!

The second act is devoted to the parting of Zhu Yingtai and Liang Shanbo. Zhu Yingtai claims she is leaving because of her concern for her aged parents. Singing shan'ge 山歌 ("mountain songs," four-line folk songs) she hints to Liang Shanbo that she is a girl and that she is in love with him, but all to no avail. In the third act Liang Shanbo, accompanied by his book-boy, arrives at the Zhu mansion for a visit to his roommate. Only now he learns that Zhu Yingtai is a girl, and that she has been engaged to a young man of the Ma 馬 family. When Liang declares that this will be his death, she promises him that she will follow

in the library of the Tōyō bunka kenkyūjo 東洋文化研究所 of Tokyo University which was presented by the author in December 1935 to Nagasawa Kikuya 長澤規矩也 (19021980). The play was reprinted (with many typos, and without the original prefaces by $\mathrm{Lu}$ Qian and Chang Renxia) in Zhou Jingshu 周静書, ed., Liang Zhu wenhua daguan: xiju yingshi juan 梁祝文化大觀戲劇影視卷 (Beijing: Zhonghua shuju, 1999), 18-28. The edition included in Shen Ning and Guo Shufen, eds. Yaxiya zhi liming: Chang Renxia xiju ji, 16-25, includes the prefaces. 
him in death. The final act opens with the entrance on stage of Zhu Yingtai's wedding procession. When it passes by Liang Shanbo's grave, Zhu Yingtai steps down from her sedan chair and sings:

\author{
[Wuye'er 梧葉兒] \\ Brother Liang, \\ If your spirit still is present,
}

Let my soul make here her home!

I truly can't believe the road to the springs indeed is blocked.

Like hovering clouds your ghost descends:

Your image wavering - it must be you?

My mind so confident—or am I wrong?

Please welcome me like a fierce gust of wind!

(Speaks:) Brother Liang, if your soul has awareness, may this grave open up so I can join you below the earth! (Sings:)

(Langlilaisha 浪裡來急)

Let us be passionate cocoons, ${ }^{13}$

Together turn into butterflies

That together to the western winds will sing a gatha of transcendence.

Down in the tomb we'll tie the knot of mutual longing,

And without day and without night

Entrust the myriad strands of foolish passion to eternity!

When Liang Shanbo's grave opens up at her prayer, she rushes into it, leaving a stupefied crowd which comments, "This happy event has suddenly been turned into a tragedy!"

Chang's Zhu Liang yuan is by all accounts a short and simple play. The cast is kept as limited as possible, the prose dialogues are short, and each act includes a very minimal number of songs. The language of the arias is quite clear and almost free of allusions, but quite lively. In a small compass it provides a relatively complete version of the legend. For the details of the plot, it borrows from the version of the legend as this circulated in southeastern Henan and the neighboring areas of northern Anhui. ${ }^{14}$ In the Henan version, one also finds, for instance, descriptions of Liang Shanbo helping out Zhu Yingtai when it is her turn to bring water from the well to the academy, and of the teacher's wife

13 This conceit is based on the homophony of "thread" ( $s i$ 絲) and “thought/longing” ( $s i$ 思). The pupa in its cocoon is believed to continue to "spit out" thread/longing until it dies.

14 Lu Xiaonong 路曉農, Lun Liang Zhu de qiyuan yu liubian 論梁祝的起源與流變 (Nanjing: Dongnan daxue chubanshe, 2014), 344-45. 
plying Zhu Yingtai with alcohol so she can take off Yingtai's boots when she has fallen asleep and find out that she has bound feet. ${ }^{15}$ It should also be highlighted that Chang's adaptation is apparently based on a version that tried to downplay Zhu Yingtai's scandalous behavior of dressing as a boy and aspiring to a man's education: in Chang's version Zhu Yingtai does not cross-dress on her own initiative, but it is her parents who have her dress as a boy and tell her to study at an academy! Chang Renxia tried to stress the local nature of his adaptation by including in the second act some Henanese shan'ge that Feng Yuanjun 馮沅君 (1900-1974) had published in the special issue of Minsu zhoukan on Liang Shanbo and Zhu Yingtai of $1930,{ }^{16}$ so I take it that for these plot elements he relied on local traditions from his hometown and deliberately kept his distance from the Jiangnan versions. By calling the events depicted in his play in its final line "a tragedy" (beiju 悲劇), he claimed for his own play of course the highest status of dramatic art, on a par with Dou Eyuan 竇娥冤 (The Injustice to Dou E) and Zhaoshigu'er 趙氏孤兒 (The Orphan of Zhao), that had been accorded this superior accolade by Wang Guowei. ${ }^{17}$

We do not know whether Gu Sui had seen Chang Renxia's Zhu Liang yuan before he wrote his own adaptation of the legend in 1936, but I think it very likely

15 Zhongguo quyi zhi: Henan juan 中國曲藝志河南卷 (Beijing: Zhongguo ISBN zhongxin, 1995), 191. Also see Zhou Jingshu ed. Liang Zhu wenhua daguan Gushi geyao juan 梁祝文 化大觀故事歌謠卷 (Beijing: Zhonghua shuju, 1999), 433-52, “Yingtai hen” 英台恨. For an English translation of this ballad from Henan as "Yingtai's Grief" see Wilt L. Idema, The Butterfly Lovers: The Legend of Liang Shanbo and Zhu Yingtai, Four versions, with Related Texts (Indianapolis: Hackett, 2010), 111-37. It should be noted that this version of the legend also circulated in areas of Hebei such as Dingxian. See "The Golden Brick" in Sidney D. Gamble, Chinese Village Plays from the Ting Hsien Region (Yang Ke Hsüan): A Collection of Forty-Eight Chinese Rural Plays as Staged by Villagers in Ting Hsien in Northern China (Amsterdam: Philo Press, 1970), 131-39.

16 Feng Yuanjun, “Zhu Yingtai de ge” 祝英台的歌, Minsu zhoukan 93-95 (Zhu Yingtai gushi $j i$ 祝英台故事集, February 1930): 61-62. The songs recorded by Feng Yuanjun had earlier been printed with her notes in Beijing daxue yanjiu nian Guoxue yuekan 3 (1925):15-17.

For a discussion of the importance of the notion of "tragedy" in the literary thought of Wang Guowei, see, for instance, He Yuming, "Wang Guowei and the Beginnings of Modern Chinese Drama Studies," Late Imperial China 28.2 (2007): 129-56. In view of the high status of tragedy in Western literary thought, and the (Japanese) claim that the Chinese dramatic tradition lacked tragedies, it became a matter of national pride to assert that China had a long tradition of tragedies. This line of scholarship eventually resulted in Zhongguo shi da gudian beiju ji 中國十大古典悲劇集, ed. Wang Jisi (Shanghai: Shanghai wenyi chubanshe), 1982. 
that he had. The academic community in China in the 193os was still very small and experts in traditional drama were few and far between. In these circles Chang Renxia's decision to have two hundred copies of his work printed must have created quite a stir, and the high praise for his zaju by Japanese scholars must have earned him both the admiration and the envy of his Chinese colleagues back home. Gu Sui may well have felt that Shionoya's praise for Chang's Zhu Liang yuan was wide of the mark and only betrayed his ignorance. Could his own play on the legend of Liang Shanbo and Zhu Yingtai have been inspired by a desire to show both his junior colleagues down in Nanjing and those self-proclaimed Japanese experts on things Chinese how it should be really done? But even if these motivations might have played a role, Gu Sui was of course too much of a gentleman to confess to such considerations.

In 1936 Gu Sui was teaching at Yanjing University outside Beijing, which had hired him in 1929 and where he would continue to teach until the end of 1941 when it was closed down by the Japanese. Gu Sui was born in Qinghe district in southern Hebei into a family of literati. He was something of a child prodigy and at the age of ten had finished reading all the books the family school had to offer. When in 1915 he had passed the admission examination for the Department of Chinese at Beijing University, he was told to go and study English because there was nothing the university could teach him in the field of Chinese literature. Following two years of initial study of English in Tianjin, he graduated from the English department of Beijing University in 1920. In the early 1920 s he worked as a middle-school teacher of English, while also publishing stories and essays in the new style of baihua 白話 literature. ${ }^{18}$ When Gu Sui moved to Yanjing University, one of his colleagues there was Zheng Qian 鄭騫 (1906-1991), one of the finest scholars of Yuan drama of the last century. ${ }^{19}$

In a letter of October 2, 1933 to Zhou Zuoren 周作人 (1885-1967), Gu Sui declared that he had decided on a five-year program to master the writing of $q u$ :

18 In the 1920 o Gu Sui wrote altogether eight short stories, one of which (Shizong 失踪) was selected by Lu Xun in the second volume of fiction in the Zhongguo xinwenxue daxi 中國 新文學大系 of $1935^{-1936 . ~}$

19 Zhao Lintao, “Gu Sui yu Zheng Qian” 顧随與鄭騫," Baoding xueyuan yuebao 28.2 (2015): 78-8o. In his years in Taiwan Zheng Qian published a one-act zaju titled Li Shishi liuluo Huxiangdao zaju 李師師流落湖湘道雜劇 (Li Shishi wanders through Hunan), in which the once famous Kaifeng courtesan, now a wandering performer, narrates the former splendor of the Song and the loss of the north following the Jürched invasion to a southern audience. See Zheng Qian, Jingwu congbian 景午叢編 1 (Taibei: Taiwan zhonghua shuju, 1972), 446-89. 
I have decided on a five-year program: for the time being I will put aside poems, lyrics, and essays, and devote myself exclusively to northern and southern songs. From sanqu I will proceed to zaju and hence to chuanqi 傳奇. Even though I cannot predict the outcome, it will at least serve to rein in my mind and energy so they will not overflow. Let's consider it my Chan training. ${ }^{20}$

Gu Sui's earliest attempt at writing a zaju, the two-act Chan xiucai 饞秀才 (The Gluttinous Student) dates indeed from 1933, but he would continue his selfimposed task only in 1936. In Chan xiucai Gu Sui portrayed in the character of its protagonist Zhao Boxing 趙伯興 the fiercely independent nature of a true literatus. ${ }^{21}$ Like Chang Renxia, Gu Sui started out with an only slightly dramatized piece of lyrical self-expression. ${ }^{22}$ For fully developed plot-based four-act plays he turned to pre-existing stories like the legend of Liang Shanbo and Zhu Yingtai. ${ }^{23}$ Gu Sui's Zhu Yingtai shenhuadie 祝英台身化蝶 (Zhu Yingtai bodily turns into a butterfly; short title Zhu Yingtai) was published in 1937 as one of the three plays included in Kushui zuoju sanzhong 苦水作劇三種 (Three Plays by Kushui) ${ }^{24}$

Gu Sui's Zhu Yingtai comes with an interesting postface:

The distribution of dramatic adaptations of the love story of Zhu Yingtai and Liang Shanbo must have been quite widespread in Yuan-dynasty times. Both the Lu gui bu 錄鬼簿 (Record of ghosts) and the Taihe

$20 \quad$ Quoted in Zhao Lintao and Gu Zhijing, "Gu Sui xueshu nianbiao," 34.

21 For discussions of this play which was first published in 1941, see Ye Jiaying 葉嘉塋, “Kushui zuoju zai Zhongguo xiqushi shang kongqian juehou de chengjiu” 苦水作劇在中 國戲曲史上空前絕後的成就, Taishan xueyuan xuebao 32.1 (2010): 8; Zuo Pengjun, “Gu Sui zaju de tizhi tongbian yu qinggan jituo” 顧随雜劇的体制通變與情感寄托, Jilin shifan daxue xuebao (July 2014): 25-26.

Chan xiucai originally only consisted of arias. Gu added dialogues and stage directions in 1942.

23 Gao Xianhong 高獻紅, “Gu Sui zaju chuangzuo zhi shimo ji xinbian” 顧随雜劇創作之 始末及新變, Hebei daxue xuebao 42.1 (2017):16-20.

24 Zuo Pengjun, Wan-Qing Minguo chuanqi zaju wenxian yu shishi yanjiu, 263-66. For this article I have based myself on the edition in Gu Sui, Gu Sui wenji 顧隨文集 (Shanghai: Shanghai guji chubanshe, 1986), 596-61o. The first complete edition of Gu Sui's six zaju was compiled by Ye Jiaying, as Ku Sui zuoju 苦水作劇 (Taibei: Guiguan tushu gongsi, 1992). Gu Sui's plays are also reprinted in the first volume of the four-volume Gu Sui quan$j i$ 顧隨全集 (Shijiazhuang: Hebei jiaoyu chubanshe, 2001), 191-312, and in the first volume of the ten-volume Gu Sui quanji (Shijiazhuang: Hebei jiaoyu chubanshe, 2014), 239-347. 
zhengyin $p u$ 太和正音譜 (A formulary of the correct sounds for an era of Great Harmony) list a play by Bai Pu titled "Zhu Yingtai Marries Liang Shanbo in Death," but it has not been transmitted. But the story still widely circulates among the people.... When I was a kid back home in the village, I saw performances of this play in the local theatrical genre of Yanggeqiang 秧歌腔. They had Liang Shanbo performed by a chou 丑, which is extremely stupid. ${ }^{25}$ Our countrymen have many taboos and that's why they don't like tragedies. Even Dou E yuan and Haishen miao 海神廟 (The Sea God's Temple) ${ }^{26}$ in Ming times were changed into chuanqi plays with a happy end, so the stories could be transmitted till today. Now when I write this today, it may be a tragedy, but my plot does not fully follow the traditional tale. Especially in the third act I have allowed myself to follow my whim, because I wanted to write my own play. Whether this story will be collected and transmitted will depend on the contemporary Grimms. ${ }^{27}$

Like Chang Renxia, Gu Sui claims that his play is a tragedy, and he even suggests that Bai Pu's lost play was not transmitted because it was a tragedy. Like Chang, Gu claims to have seen performances of plays on the legend of Liang Shanbo and Zhu Yingtai while a child, and one would therefore expect him to base his plot on the local version of the legend. The closest parallel to the plot of Gu Sui's play I have been able to locate so far, however, is the plot of the legend as narrated by Feng Yuanjun who hailed from Tanghe in southwestern Henan. According to this version, the future parents of Liang Shanbo and Zhu Yingtai are good friends, and when both couples are expecting they agree that if the two children turn out to be a boy and a girl, they should be married. But by the time the babies are born, the Liang family has fallen on hard times and

25 The chou is the role-type that portrays simpleminded folks. As a young student Liang Shanbo is usually performed by a sheng 生, the role-type that portrays handsome young lovers. The local Yanggeqiang opera in Qinghe, however, was not the only genre to have Liang Shanbo performed by a chou, as that was also the role-type for Liang Shanbo in Hongdong opera from Shanxi in the nineteenth century. See Zhou Jingshu ed., Liang Zhu wenhua daguan: Xiju yingshi juan, 392-401. On pp. 397-98 the editor suggests that Liang Shanbo's role-type in this text may reflect the situation in many local genres of skits where the role types are limited to chou and dan.

Haishen miao is an early southern play. In this play a courtesan is betrayed by her former lover after he has passed the examinations. The courtesan then commits suicide and her ghost takes revenge by driving her unfaithful lover mad. The play is named after the temple where the couple swears eternal loyalty to each other before the student leaves for the capital to take the examinations.

Gu Sui, Gu Sui wenji, 61o. 
Mr. Zhu has died, whereupon his widow reneges on the engagement pledge by claiming that she gave birth to a boy. When later Liang Shanbo has reached the age to go to school, the Liang family invites the "boy" of the Zhu family to accompany him, so her mother dresses Zhu Yingtai as a boy until she becomes too old for this charade. Liang Shanbo and Zhu Yingtai love each other very much, but they don't know they have been promised to each other, and Liang Shanbo does not understand her hints when she leaves the school. When later Liang Shanbo visits the Zhu mansion, he finds out Zhu Yingtai is a girl and is engaged to someone else, because of which he falls ill and dies, and Zhu Yingtai joins him in the grave on the day of her marriage. ${ }^{28}$

Like Zhu Liang yuan, Gu Sui's play is a regular four-act zaju, in this case including a wedge in front of the third act. Once again, the four main sets of songs are assigned to the dan 且who plays Zhu Yingtai. In the first act, Zhu Yingtai enters the stage dressed in male attire. She informs the audience that she is her parents' only child and has been dressed as a boy since her earliest youth. Her parents had engaged her "in the womb" to Liang Shanbo, who has lost both his parents and does not know about the arrangement. Following the death of her mother, her father has turned his back on the engagement, but still allows Liang Shanbo to study with her in the family school. When Liang Shanbo joins her in the classroom, Zhu Yingtai praises him highly, but when the teacher enters and asks them to come up with a parallel line to a phrase set by him, Zhu Yingtai easily outperforms him. When the teacher leaves, she invites Liang Shanbo to accompany her to the spring garden:

(Female and male act out walking together and entering the garden. Female speaks:) Brother, just look! [Daodaoling 叨叨令]

Flaming red: the whole garden seems on fire as spring buds have opened; Drifting afar: all of the sky seems a haze now willow floss stirs; Rippling and blue: below the red-lacquered bridge the clear waves wax. I feel languorously lazy, too ashamed, weak as I am, to ascend the swing. Let me ask you: do you perhaps understand?

28 Feng Yuanjun, "Zhu Yingtai de ge," 63-64. I take it for granted that Gu Sui was acquainted with the special issue of Minsu zhoukan in which this little article appeared, or with the earlier publication in Guoxue yuekan. Zhu Yingtai's cross-dressing as a result of a broken marriage promise would appear to be a plot element that was quite widespread in Henan and adjoining areas. In southern versions in which Zhu Yingtai is dressed as a boy from birth the parents are confronted with clan rules that only allow sons to inherit. For the regional distribution of these plot elements see Xu Duanrong 許端容, Liang Zhu gushi yanjiu 梁祝故事硏究 4 (Taipei: Xiuwei zixun keji, 2007), 1385, 1493, 1502-3. 
Let me ask you: do you perhaps understand?

Because of this I'm overcome by longing:

Plucking a sprig, not saying a word, my heart so pensive and wistful!

(Female speaks:) Brother, do you fathom my spring sorrow? (Male speaks:) The spring is a time for having fun. What sorrow could there be? (Female acts out heaving a sigh, and speaks:) So you cannot fathom it! (Sings:)

[Sansha 三怱]

You cannot hear at all the oriole that's singing hidden among the peach blossoms,

You cannot feel at all the green that fills the banks as fragrant herbs first grow.

You too must see the drifting threads that in the air float upwards without wind,

The busy bees below the flowers that seek fragrance everywhere! Brother, you may understand the ritual system of the Duke of Zhou, The Odes as edited by Master Kong, and the fine writings of Sir Zuo, But you don't understand the intertwining branches of the trees, The coupling of all creatures!

(Male speaks:) I don't understand a word of what you are saying. I'm hungry. Goodbye brother. I'm going home to have a meal.

And as Liang Shanbo departs to have a bite, he leaves a frustrated Zhu Yingtai behind. By the second act, we have moved one year forward. Zhu Yingtai still enters in male dress, but tells us that she is not allowed to see Liang Shanbo anymore because she has grown up. Even as Liang Shanbo is leaving for the examinations, her father does not allow her to receive him, so behind her father's back she decides to see Liang Shanbo off at a pavilion by the river. At the pavilion she wishes Liang Shanbo all the best and deplores her own fate, but Liang Shanbo does not understand her feelings, leaving her in tears.

The wedge in Gu Sui's Zhu Yingtai is given over to Liang Shanbo. He has not only failed to pass the examination, but he also has been informed by an uncle that the Zhu Yingtai he always believed to be a boy is not only a girl, but also the girl that had been promised to him in marriage. He now understands what she wanted to say to him, but also has learned that her father has now promised her in marriage to student Ma. Overcome by emotions, he falls ill and dies. In the following third act, Zhu Yingtai enters dressed as a girl. She has learned of the death of Liang Shanbo and is wondering whether he knew before his death that she was a girl. When she hears migrating geese passing outside, she blames them for calling out even though they are flying together. When she 
falls asleep, she dreams that she is visited by Liang Shanbo who urges her to pluck the red flower, rooted in his heart, that has grown on his grave, when she will be taken to the Ma family on her wedding day, which leaves her puzzled when she awakes. The fourth act opens with the entrance of student Ma (played by a jing 淨), who knows she loves Liang Shanbo but nevertheless looks forward to a happy marriage ("Once the fat duck has been cooked, it won't fly off to heaven.") Whereas many versions of the legend of Liang Shanbo and Zhu Yingtai make a point of stressing that the bride Yingtai is dressed in mourning, in this play she enters the stage in all her finery. When the wedding procession headed by Student Ma passes by the grave of Liang Shanbo, she first asks student Ma to pluck the red flower for her, but when he is unable to do so, she insists on plucking it herself and sticks it in her hair. At her prayer, the grave then opens up, but in the good fashion of Italian opera, she only steps into it after a final dazzling aria.

([Female] speaks:) Brother, the dream has been proven true. Now display some more of your divine power to that nincompoop. (The grave opens up with an explosive sound. The clown collapses in fright, and speaks:) How terrifying! (Female sings:)

[Litingyan 離亭宴 followed by Xiezhisha 歇指煞]

I suddenly see the hullabaloo of one gust of mad wind scatter the wilted leaves,

The swirling waves of yellow dust on all sides raise the remnant snow:

It fully seemed as if in a roaring rumble the hills fell down, the earth was wracked!

No talk anymore of the cold and forlorn shadows drifting in the evening glow,

Of the endless expanse of darkening clouds at the distant horizon, Of the transparent gleam on murmuring streams of mountain brooks. You over there: bitterly tragic, your century of grief an eternal sorrow; I over here, shivering with cold: the piercing frost of the heart of winter! I cannot stop the tears trickling down on my cheeks from flowing on. I only thought that with a sizzling sound the clear star had fallen from the blue welkin,

That deeply so deeply the white jade had been buried in the yellow earth, That nowhere to be found the bright moon had sunk into the gray ocean, That from now on the distant view of a thousand years would offer no fine spring,

The endless procession of millions of autumns would resemble one eternal night, 
But then in fact most majestically your divine power still exists! Student Ma, go home by yourself all alone to the wedding awning! Liang Shanbo, let's go off, united together, to the Yellow Springs!

(Female acts out stepping into the tomb, and exits. Clown acts out immediately jumping into the tomb that has closed and does not admit him, and speaks:) This tomb is way too exclusive! (Recites a poem:) From the day Pangu opened heaven and earth down to the present, One's never seen a living person jumping into the grave of a stiff. Now watch me: whether I'll have to die or to turn into a monster, I'll not allow that couple to turn into rain and to turn into clouds! ${ }^{29}$ (Acts out dying by butting his head [against the tomb], and exits.)

After Yingtai's maid in a final poem has blamed Yingtai's father for causing this tragedy, two yellow butterflies flutter across the empty stage, followed closely by a white butterfly as Student Ma is turned into a butterfly too.

Moving the action in the first act from the academy to the family school, $\mathrm{Gu}$ Sui's version goes beyond Chang's adaptation in exculpating Zhu Yingtai, whose love for Liang Shanbo is now a passion that has been pre-ordained by her parents when they promised her to him even before her birth. ${ }^{30}$ Switching the deceased parent from the father to the mother may have been inspired by the thought that a father makes for a more fitting representative of parental power than the mother. If the common study of Liang Shanbo and Zhu Yingtai took place during their primary school days, Gu Sui may have drawn the logical conclusion that the action must have taken place in their home village and not in some faraway academy. If that is the case, the parting scene also must be redesigned, and it would be an obvious choice to have Liang Shanbo depart for the capital in order to sit for the exams. In his postface Gu Sui claimed that he was most original in the third act of his play. A Zhu Yingtai lamenting her fate, once she learns of Liang Shanbo's death, is of course a fixture of practically all versions of the legend. More original may be the objective correlative of her grief. No end of poets have been moved to grief by the lonely call of a goose

29 "Clouds and rain" is the classic Chinese euphemism for having sex.

30 In his “Guanyu Liang Shanbo Zhu Yingtai gushi” 關於梁山伯祝英台故事, an article originally published in the Renmin ribao of March 18, 1951, He Qifang 何奇芳 (1912-1977) lambasted a critic who had complained about a lack of fighting spirit in Zhu Yingtai in a play on Liang Shanbo and Zhu Yingtai that had been published in 1950 in Hebei and was based on earlier plays on the legend in Pingju and Yanggexi. If that play and Gu Sui's zaju reflected the same local tradition, the complaint about the lack of fighting spirit becomes quite understandable. He Qifang's article has been repeatedly been reprinted. I have consulted the edition in Zhou Jingshu ed., Liang Zhu wenhua daguan: xueshu lunwen juan 梁祝文化大觀學術論文卷 (Beijing: Zhonghua shuju, 1999), 39-51, esp. 45. 
that has lost its companions, but here Zhu Yingtai is moved to sadness by flocks of geese.

The red flower that blooms on Liang Shanbo's grave in the middle of the winter may well be Gu Sui's own addition to the story. Rooted in Liang Shanbo's heart, it can only be plucked by Zhu Yingtai. A red flower in the shape of a peony is also encountered in many other versions of the legend (some of which are called "tale of the peony"), but in those cases it is a symbol of Zhu Yingtai's virginity: on leaving home to study at an academy she vows she will guard her virginity and that the blooming peony will only wilt when she breaks that vow. $\mathrm{Gu}$ Sui's flower may well derive from the fairy-tale literature of romantic nineteenth-century Europe, as he seems to betray in his reference to the Grimm brothers in the final line of his postface. When discussing her teacher's plays, Ye Jiaying 葉嘉瑩 has repeatedly stated that Gu Sui's most original and important contribution to the history of Chinese dramatic literature was that he imbued his plays with a symbolic meaning, but adds that he did so least of all in his Zhu Yingtai. ${ }^{31}$ But in her introduction to his collected plays of 1992 she very much stresses the importance of the red flower as a symbol of a sincere passion that is so strong it transcends life and death. ${ }^{32}$ The importance of the addition of the red flower is also much stressed by Gu Sui's daughter Gu Zhijing 顧之京. ${ }^{33}$ As an expression of Liang Shanbo's undying burning passion, the flower also goes a long way to redeem his character. Gu Sui may have changed the role-type of Liang Shanbo from a chou to a mo 末, but his Liang Shanbo in the first two acts of his play is still very much a simpleton. It is only upon his death that Liang Shanbo gains the strength to claim Zhu Yingtai.

\section{Conclusion}

Throughout the first half of the twentieth century the legend of Liang Shanbo and Zhu Yingtai remained a popular item in basically every genre of regional opera, and the plays were continuously adapted to take advantage of new stage

31 Ye Jiaying, “Kushui zuoju zai Zhongguo xiqushi shang kongqian juehou de chengjiu” 苦水 作劇在中國戲曲史上空前絕後的成就, Taishan xueyuan xuebao 32.1 (2010): 9. In the same article she quotes her teacher's offhand dismissal of earlier playwrights as "vulgar, superficial, absurd, and nonsensical" (p. 4).

32 Ye Jiaying, “Gu Xianji xiansheng juzuo zhongzhi xiangyu yiwei, daixu” 顧羡季先生劇作 中之象喻意味, in Kushui zuoju, 6-7.

33 Gu Zhijing, Nü'er yanzhong de fuqin: dashi Gu Sui 女兒眼中的父親: 大師顧随 (Beijing: Zhongguo Gongren chubanshe, 2007), 16o-63. 
design and changing theatrical technology. ${ }^{34}$ This popularity remained undiminished in the first seventeen years of the People's Republic, ${ }^{35}$ when it was further strengthened by the new medium of film. ${ }^{36} \mathrm{~A}$ silent movie based on the legend had been shot as early as 1926, and in 1954 China's first full-color feature movie was an adaptation of the Yueju 越劇 version of the love story, which was re-released to great popular acclaim in 1978. Outside the PRC, the 1967 Shaw Brothers' Huangmeidiao 黃梅調 adaptation as Love Eterne was a runaway success. In recent decades spoofs and parodies continue to testify to the popularity of the legend. ${ }^{37}$

Chang Renxia's Zhu Liang yuan and Gu Sui's Zhu Yingtai had no connection to the vibrant world of the contemporary commercial theater. While it is likely that the conception of their two plays was at least partly inspired by local versions that the authors had watched in their youth, these plays were not written to replace these. There is also no indication that either author made any serious attempts to have his play performed. It is of course also difficult to imagine how these two plays could have been performed. The true music of Yuan drama is lost, and inasmuch as Chang Renxia and Gu Sui were more successful in adhering to the prosodic rules of early zaju, it would be more difficult to perform these plays in Kunqu. A performable Kunqu adaptation of the legend only arrived in the early twenty-first century, when Zeng Yongyi 曾永義 produced his Liang Shanbo yu Zhu Yingtai 梁山伯與祝英台. ${ }^{38}$

Zhu Liang yuan and Zhu Yingtai were both born as closet drama. Recent scholarship has evinced a growing appreciation of the premodern genres of Chinese literature, such as poetry, as they were still practiced in Republican times. If this ever leads to an overhaul of the history of Chinese literature in the first half of the twentieth century and a redesigned curriculum for Chinese

34 Zhou Jingshu and Shi Xiaofeng 施孝峰, Liang Zhu wenhua lun 梁祝文化論 (Beijing: Renmin chubanshe, 2010), 165-75. Jin Jiang, Women Playing Men: Yue Opera and Social Change in Twentieth-century Shanghai (Seattle: University of Washington Press, 2009), ${ }^{102-5}$ discusses the continuous revision of the Yueju opera on Liang Shanbo and Zhu Yingtai in the 1940s.

35 Hsiao-mei Hsieh, "Where Have All the Different Butterfly Lovers Gone? The Homogenization of Local Theater as a Result of the Theater Reform in China as seen in Gezai xi/ Xiangju," Chinoperl Papers 30 (2011): 103-22.

$36 \quad$ Xu Lanjun, "The Lure of Sadness: The Fever of Liang-Zhu and the Yue Opera in the 195os China," Asian Theater Journal 33 (2016): 104-127.

37 Shi Lijuan 師麗娟, “Huwenxing shiyu zhongde Liang Zhu gushi zhi dangdai gaibian” 互文性視域中的梁祝故事之當代改編, Taiyuan ligong daxue xuebao 35.1 (2015): 7175 .

38 Zeng Yongyi and Zhou Qin 周秦, Pengying wunong 蓬瀛舞弄 (Taibei: Guojia chubanshe, 2016), 3-145. 
literary history, perhaps some space can be reserved too for a consideration of these plays as the last masterworks of a fading tradition, testifying to the complexity and variety of Chinese literature and art in the Interbellum. 